\title{
Preparation and characterization of microcapsules of Pterodon pubescens Benth. by using natural polymers
}

\author{
Alexandre Espada Reinas, Jaqueline Hoscheid, Priscila Miyuki Outuki, \\ Mara Lane Carvalho Cardoso*
}

Pharmacy Department, State University of Maringá, Maringá, PR, Brazil

\begin{abstract}
An oleaginous fraction obtained from an alcohol extract of the fruit of Pterodon pubescens Benth. (FHPp) was microencapsulated in polymeric systems. These systems were developed using a complex coacervation method and consisted of alginate/medium-molecular-weight chitosan (F1-MC), alginate/ chitosan with greater than $75 \%$ deacetylation (F2-MC), and alginate/low-molecular-weight chitosan (F3-MC). These developed systems have the potential to both mask the taste of the extract, and to protect its constituents against possible chemical degradation. The influence of the formulation parameters and process were determined by chemical profiling and measurement of the microencapsulation efficiency of the oleaginous fraction, and by assessment of microcapsule morphology. The obtained formulations were slightly yellow, odorless, and had a pleasant taste. The average diameters of the microcapsules were $0.4679 \mu \mathrm{m}$ (F2-MC), $0.5885 \mu \mathrm{m}$ (F3-MC), and $0.9033 \mu \mathrm{m}$ (F1-MC). The best formulation was F3-MC, with FHPp microencapsulation efficiency of $61.01 \pm 2.00 \%$ and an in vitro release profile of $75.88 \pm 0.45 \%$; the content of vouacapans $3-4$ was $99.49 \pm 2.80 \%$. The best model to describe the release kinetics for F1-MC and F3-MC was that proposed by Higuchi; however, F2-MC release displayed firstorder kinetics; the release mechanism was of the supercase II type for all formulations.
\end{abstract}

Uniterms: Pterodon pubescens Benth./pharmacognosy. Sucupira. Microcapsules/preparation. Vouacapans. Alginate. Chitosan. Coacervation method. Natural polymers. Natural products.

Uma fração oleaginosa obtida do extrato etanólico de frutos de Pterodon pubescens Benth (FHPp) foi microencapsulada em um sistema polimérico. Estes sistemas foram desenvolvidos utilizando o método de coacervação complexa, constituído de alginato/quitosana massa molecular média (F1-MC), alginato/ quitosana com desacetilação superior a 75\% (F2-MC) e alginato/quitosana de massa molecular baixa (F3-MC). Estes sistemas desenvolvidos têm o potencial tanto de mascarar o sabor do extrato, quanto de protegê-lo de possível degradação química. A influência dos parâmetros de formulação e processo foram determinadas por caracterização química, determinação da eficiência de microencapsulação da fração oleaginosa e por avaliação morfológica da microcápsula. As formulações mostraram-se ligeiramente amareladas, inodoras e com sabor agradável. Os diâmetros médios das microcápsulas foram de 0,4679 $\mu \mathrm{m}$ (F2-MC), 0,5885 $\mu \mathrm{m}$ (F3-MC) e 0,9033 $\mu \mathrm{m}$ (F1-MC). A melhor formulação foi F3-MC, considerando-se que apresentou eficiência de encapsulação de $61,01 \pm 2,00 \%$, e perfil de liberação in vitro de 75,88 \pm 0,45\%; o conteúdo dos vouacapanos 3-4 foi 99,49 $\pm 2,80 \%$. O melhor modelo para descrever a cinética de liberação foi o modelo proposto por Higuchi para F1-MC e F3-MC, entretanto, para F2-MC foi o modelo de primeira ordem, e o mecanismo de liberação foi do tipo super caso II para todas as formulações.

Unitermos: Pterodon pubescens Benth./farmacognosia. Sucupira. Microcápsulas/preparação. Vouacapanos. Alginato. Quitosana. Método de coacervação. Polímeros naturais. Produtos naturais.

\footnotetext{
*Correspondence: Mara Lane Carvalho Cardoso. Departamento de Farmácia, Centro de Ciências da Saúde, Universidade Estadual deMaringá. Avenida Colombo, 5790 - BlocoK80. Zona Sete, 87020-900-Maringá -PR, Brasil. E-mail address: mlanecc@yahoo.com.br
} 


\section{INTRODUCTION}

"Sucupira" is the common name given to several species of the genera Pterodon and Bowdichia, both of which belong to the Leguminosae family. The oil extracted from the fruit of the Pterodon sp. has been shown to have several pharmacological properties including anticancer, antinociceptive, and anti-inflammatory activity, and has been studied mainly for its effects on arthritis (Carvalho et al., 1999; Coelho et al., 2005; Vieira et al., 2008; Hoscheid et al., 2013). The raw oil extract is difficult to use in pharmaceutical preparations without protection of its lipophilic constituents, which are easily oxidized by exposure to air and light.

Natural polymers have potential pharmaceutical applications as protectants because of their low toxicity, biocompatibility, biodegradability, low cost, and natural abundance (Mahkam, 2009). Therefore, the use of both alginate and chitosan has been proposed for drug delivery. Alginates are natural polymers isolated from several species of brown algae and are composed of 2 monomers, $\alpha$-L-guluronic acid and $\beta$-Dmannuronic acid. Chitosan, another natural polymer derived from chitin, is a linear molecule consisting of D-glucosamine residues with a variable number of randomly located $N$-acetyl glucosamine groups (Mahkam, 2009).

Microencapsulation is a technique that enables solid or liquid substances to be added to polymeric matrices or to be coated with polymers (Nesterenko et al., 2013; Uddin, Hawlader, Zhu, 2001; Venkatraman et al., 2000). The oldest, and probably the most widely used, microencapsulation technique involves phase separation by coacervation. This consists of polymer deposition around the active agent by modification of the medium's physico-chemical properties, such as temperature, ionic strength, $\mathrm{pH}$, and polarity (Suave et al., 2006). This technique involves the reversible association of two polymers and has some advantages over other techniques, including the possibility of using biopolymers, the absence of an organic solvent, and mild temperature conditions during processing (Kruif, Weinbreck, Vries, 2004; Schmitt et al., 1998).

In light of this knowledge, the objective of the present study was to develop coacervation methods to prepare the oleaginous fraction obtained from an alcohol extract of the fruit of Pterodon pubescens Benth. (FHPp). The microcapsules were prepared using natural polymers and then characterized.

\section{MATERIAL AND METHODS}

\section{Material}

Alginate with a fraction of 0.28 guluronic acid was obtained from Sigma-Aldrich (São Paulo, Brazil). $\mathrm{CaCl}_{2}$ and Tween 80 were purchased from Vetec (Duque de Caxias, Brazil). Chitosan with an average molecular weight, chitosan with $\geq 75 \%$ deacetylation, and lowmolecular-weight chitosan were obtained from SigmaAldrich (São Paulo, Brazil).

\section{Methods}

\section{Plant material and extraction}

$P$. pubescens seeds were obtained from the state of Nossa Senhora do Livramento, Mato Grosso, Brazil. The taxonomic identity of the respective trees was confirmed by Dr. Germano Guarim Neto from the Herbarium of the Federal University of Mato Grosso, and a voucher specimen (no. 20502) was deposited at the herbarium of the State University of Maringá.

A crude extract of $P$. pubescens was obtained and fractionation was performed as previously reported (Hoscheid et al., 2012). Dried fruits of P. pubescens were extracted with ethanol by turbo extraction (Ultra-Turrax UTC115KT, IKA Works, Wilmington, NC, USA) and the extract was filtered. The filtrate was diluted with water and partitioned with hexane. The organic solvent was evaporated in a vacuum evaporator (Büchi ${ }^{\circledR} \mathrm{R}-114$, Flawil, Switzerland) at $40^{\circ} \mathrm{C}$ until complete evaporation of the solvent, to obtain the oleaginous fraction (FHPp).

\section{Chemical characterization of FHPp of the alcohol extract of $P$. pubescens by gas chromatography coupled with mass spectrometry}

Gas chromatography coupled with mass spectrometry (GC-MS) was performed using a system equipped with Thermo Electron Corporation Focus GC, DSQ II (Marietta, USA), with an HP-5 capillary column $(30 \mathrm{~m} \times 0.25 \mathrm{~mm})$. The chromatographic conditions and the monitoring of mass fragments (GC-MS-SIM) were carried out in accordance with the methodology previously described by Hoscheid et al. (2012), and vouacapan concentration was monitored using the calibration curve developed and validated by the same author.

\section{Preparation of cross-linked alginate/chitosan microcapsules with $\mathrm{CaCl}_{2}$}

For the preparation of formulations F1-MC, F2-MC and $\mathrm{F} 3-\mathrm{MC}, 2.50 \%$ alginate solution $(\mathrm{w} / \mathrm{v})$ containing 
$0.25 \%$ Tween $80(\mathrm{w} / \mathrm{w})$ and $72.13 \%$ FHPp (w/w) was emulsified. This emulsion was atomized using an atomizer with a nozzle diameter of $0.7 \mathrm{~mm}$ on a $0.10 \%$ chitosan solution $(\mathrm{w} / \mathrm{w})$ in acetic acid $1 \%(\mathrm{v} / \mathrm{v}) / \mathrm{CaCl}_{2}$ $2.0 \%(\mathrm{w} / \mathrm{v})$ that was previously homogenized at 4000 $\mathrm{rpm}$. Atomization was performed at a flow rate of $1 \mathrm{~mL} /$ min and pressure of 0.5 bar. All tests were performed under the same conditions by changing only the type of chitosan used: F1-MC was prepared using mediummolecular-weight chitosan, F2-MC using chitosan with $\geq 75 \%$ deacetylation, and $\mathrm{F} 3-\mathrm{MC}$ using low-molecularweight chitosan. The whole process was conducted in an ice bath maintained at a temperature of $-4{ }^{\circ} \mathrm{C}$. The microcapsules were washed with water, coarsely filtered, centrifuged at $3600 \mathrm{rpm}$, and freeze-dried. Blank microcapsules were prepared without FHPp, but using the same conditions as those used for the FHPploaded microcapsules. All formulations were prepared in triplicate.

\section{Morphology and particle size analysis}

The microcapsule surfaces were analyzed using scanning electron microscopy (SEM; Shimadzu SS550 Super Scan, Kyoto, Japan) and a metallizer IC 50 ion coater. Particle size analysis was performed using Image Pro Plus software (version 4.5.0.29 for Windows) using Feret's diameter as a parameter (Barber, 1993). We measured at least 1000 particles and determined their size distribution.

\section{Thermogravimetric analysis and differential scanning calorimetry}

Thermogravimetric analysis (TGA) and differential scanning calorimetry (DSC) of the polymers, FHPp, and microcapsules were performed in order to evaluate the variations in the temperature-mass relationship of the materials, and to evaluate possible interactions between the polymers and FHPp. The analyses were carried out using a simultaneous analyzer (NETZSCH STA 409 PC Luxx ${ }^{\circledR}$, Witterlsbacherstr, Germany) under a nitrogen atmosphere, with a flow rate of $50 \mathrm{~mL} / \mathrm{min}$ and heating rate of $10^{\circ} \mathrm{C} / \mathrm{min}$, over a temperature range of 25 to $600^{\circ} \mathrm{C}$.

\section{$X$-ray diffraction}

The X-ray diffraction (XRD) analysis of the polymers, FHPp, and microcapsules was performed using an X-ray diffractometer (Shimadzu LabX XRD-6000, Kyoto, Japan) at Cuk $\alpha_{1}, 0.1542 \mathrm{~nm}, 40 \mathrm{KV}$, and $40 \mathrm{~mA}$. Scans were performed between intervals of $2 \theta$; the range was $5^{\circ}$ to $90^{\circ}$, and the speed was set at 0.5 degrees with $2 \theta / \mathrm{min}$.

\section{Fourier transform infrared spectroscopy}

Infrared spectroscopy analysis of the polymers, FHPp, and microcapsules was carried out using a Fourier transform infrared spectrophotometer (FTIR; BOMEN, MB-100C26, Quebec, Canada) at a range of 400 to 4000 $\mathrm{cm}^{-1}$ and a resolution of $1 \mathrm{~cm}^{-1}$ with samples in $\mathrm{KBr}$ pellets.

\section{Fourier transform Raman spectroscopy}

Fourier transform Raman (FT-Raman) spectroscopy analysis of the polymers, FHPp, and microcapsules was conducted using an FT-Ram II (Bruker, Vertex 70V, Ettlingen, Germany), with the following parameters: power, 200-250 mW; scans, 100-1500; resolution, $4 \mathrm{~cm}^{-1}$; crack, $5 \mathrm{~mm}$; and wavelength, $1064 \mathrm{~nm}$.

\section{Microencapsulation efficiency of the oleaginous fraction and content of microencapsulated vouacapans}

Loaded microcapsules (200 mg) were extracted with hexane $(110 \mathrm{~mL})$ by leaching, over $2 \mathrm{~min}$, at room temperature, and filtered. The solvent was removed in a vacuum evaporator, and the extractable core material was dried at $80^{\circ} \mathrm{C}$ for $40 \mathrm{~min}$ for evaporation of the residual solvent. The microencapsulation efficiency (ME\%) was calculated using the following formula:

$\mathrm{ME} \%=($ Experimental percentage of FHPp content in the microcapsules/Theoretical percentage of FHPp content in the microcapsules) $\mathrm{x} 100$.

The extractable material was resuspended in $2 \mathrm{~mL}$ of chloroform for injection and subsequent calculation of the vouacapan concentration (Vouacapan \%) present in the loaded microcapsules was determined using GC-MS-SIM analysis.

\section{In vitro release profile}

In vitro release profiling was carried out according to United States Pharmacopeia 32 (2009). Briefly, microcapsules $(760 \mathrm{mg}$ ) were accurately weighed and placed directly on dissolution test apparatus I (Erweka, DT-800, Heusenstamm, Germany) with a mesh size between 0.36 and $0.44 \mathrm{~mm}$ at $100 \mathrm{rpm}$ and $37 \pm 0.5^{\circ} \mathrm{C}$. The profiles were determined in sink conditions, with $500 \mathrm{~mL}$ of buffer 1.2. After $180 \mathrm{~min}$, the dissolution medium was replaced with $500 \mathrm{~mL}$ of buffer 6.8. Samples with a volume of $5.0 \mathrm{~mL}$ were collected at $30,60,90$, $150,180,240,300,480,720$, and $1440 \mathrm{~min}$, by volume replacement, for calculating the vouacapan concentration in the microencapsulated FHPp, by using GC-MS-SIM. All release tests were performed in triplicate.

To determine the release mechanism, the results were analyzed using the general equation describing 
the release of the drug from polymeric matrix systems (Korsmeyer et al., 1983; Peppas, 1985).

\section{Statistical analysis}

Data are presented as means \pm standard deviation (S.D.). Results were analyzed using STATISTICA ${ }^{\circledR} 10.0$ software (Statsoft, Oklahoma, USA). Analysis of variance (ANOVA) and the post-hoc Tukey's test were used to evaluate the encapsulation efficiency. $P$ values of $<0.05$ were considered statistically significant.

\section{RESULTS AND DISCUSSION}

\section{Chemical profile}

The GC-MS-SIM chemical profile of FHPp after microencapsulation (Figure 1) remained unchanged when compared with that of FHPp, i.e., the major constituents, geranylgeraniol and vouacapans, remained stable. The transformation of raw plant materials into drugs should preserve the pharmacological and chemical integrity of constituents, ensuring their potential therapeutic value and maintenance of their biological effect and use (Miguel, Miguel, 1999).

Vouacapans are furanoditerpenes involved in the antirheumatic, antinociceptive, and anti-inflammatory activities of the oil extracted from $P$. pubescens fruit (Carvalho et al., 1999; Nunan, Carvalho, Piloveloso, 1982; Silva et al., 2004; Spindola et al., 2009; Spindola et al., 2010). Earlier studies by our group have identified the presence of 2 vouacapans in FHPp that may be directly involved in their potential therapeutic activity: methyl $6 \alpha$-acetoxy-7 $\beta$-hydroxyvouacapan-17 $\beta$-oate (vouacapan 3 ) and methyl $6 \alpha$-hydroxy-7 $\beta$-acetoxyvouacapan-17 $\beta$-oate (vouacapan 4) (Hoscheid et al., 2012). However, the main compound extracted from FHPp was previously identified as 14,15-epoxygeranylgeraniol (retention time $33.38 \mathrm{~min}$ ) (Hoscheid et al., 2012; Mors et al., 1967) and has been reported to be effective as a chemoprophylactic against schistosomiasis (Mors et al., 1967).

\section{Morphological and particle size analysis}

SEM photomicrography indicated that the microcapsules were spherical, flat, and formed clusters (Figure 2(a), (b), and (c)). This agglomeration is characterized by the residual chitosan in the process of cleaning tools. Similar results were found by Mladenovska et al. (2007), by analyzing micrographs of alginate/ chitosan particles in 5-aminosalicylic acid. The surface of the microcapsules prepared in the present study appeared
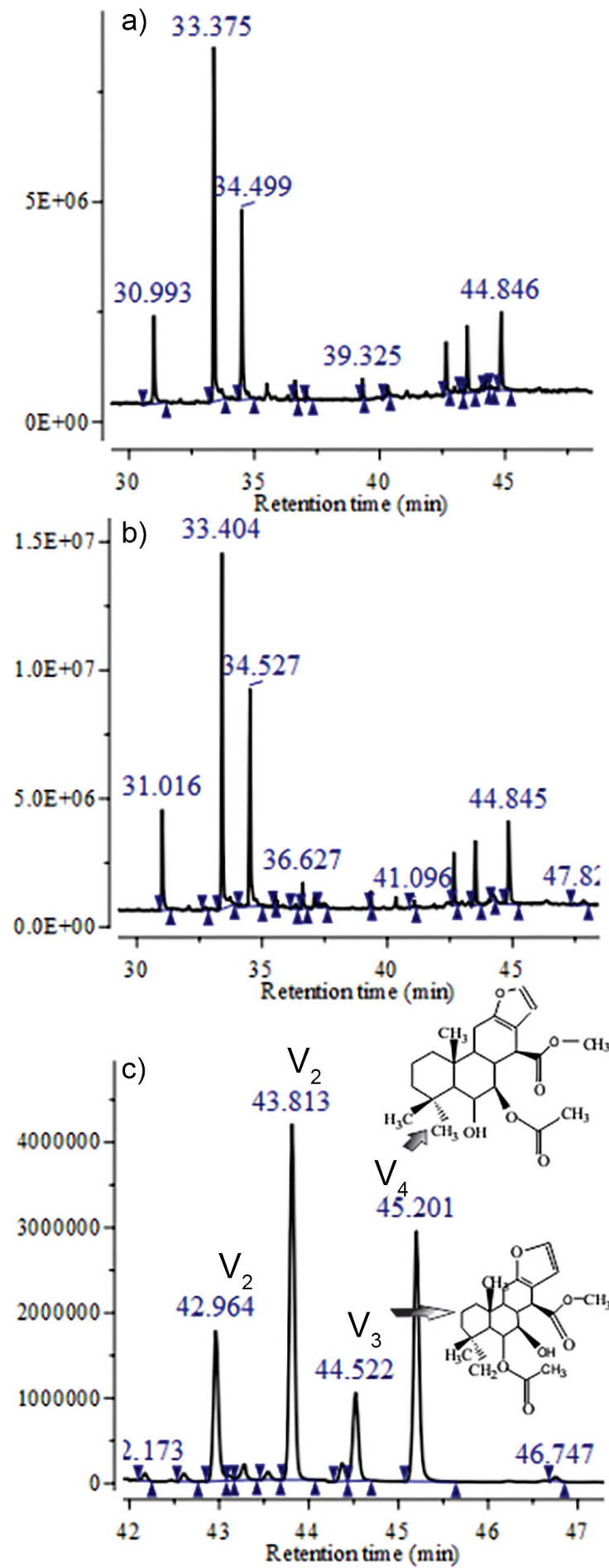

FIGURE 1 - Chemical profile of FHPp before (a) and after (b) the process of microencapsulation (F1-MC, F2-MC, F3-MC) by GC-MS-TIC, and identifying of vouacapans quantified by GC-MS-SIM (c). Compounds with a retention time between 30 and $37 \mathrm{~min}$, are derived from the geranylgeraniol. Compounds with a retention time between 39 and $45 \mathrm{~min}$, correspond to vouacapans. V1 and V2 = not identified; V3 = methyl $6 \alpha$-acetoxy-7 $\beta$-hydroxyvouacapan-17 $\beta$-oate;

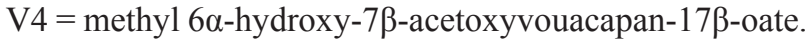



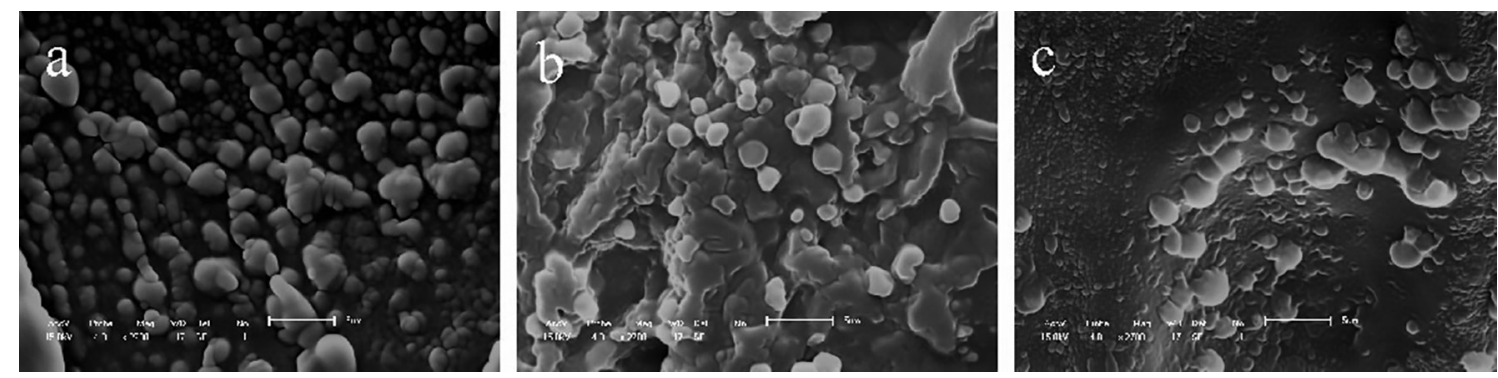

FIGURE 2 - Photomicrography obtained by scanning electron microscopy of microcapsules obtained from polymeric associations: F1-MC (a); F2-MC (b); F3-MC (c) (2700x).

porous and wrinkled, a feature of the alginate polymer used (Pasparakis, Bouropoulos, 2006).

The particle size analysis revealed that F2-MC had a lower mean diameter than the other formulations. The diameters of F1-MC, F2-MC, and F3-MC were 0.9033 $\pm 0.48 \mu \mathrm{m}, 0.4679 \pm 0.21 \mu \mathrm{m}$, and $0.5885 \pm 0.33 \mu \mathrm{m}$, respectively. Furthermore, the polydispersion index was determined as 0.9300 for F1-MC, 0.7234 for F2-MC, and 0.7467 for F3-MC.

\section{ME\% of the oleaginous fraction and Vouacapan $\%$}

The results of the encapsulation yield analysis (Table I) showed that the best association was provided by F3-MC, a fact confirmed by the Vouacapans $\%$. These results were similar to those obtained by Peniche et al. (2004), who in a study of encapsulation of alginate/ chitosan in shark liver oil showed that increasing the concentration of alginate improves the capsule oil content. However, the present work was limited by the capacity of the peristaltic pump of the spray-dryer that could not atomize concentrations higher than $3 \%(\mathrm{w} / \mathrm{v})$, which would provide enhanced results according the previous study by Peniche et al. (2004). The alginate reacts with divalent cations such as $\mathrm{Ca}^{+2}, \mathrm{Sr}^{+2}$, and $\mathrm{Ba}^{+2}$, which replace the sodium ions in guluronic acid, forming a network structure (Shi et al., 2011). Thus, the ratio of guluronic acid should be higher to enhance the encapsulation process.

The content of microencapsulated vouacapans 1 obtained for all formulations was low $(<50.00 \%)$, indicating that the type of polymer network created by alginate associated with chitosan, was not sufficient for microencapsulation. However, it should be noted that the Vouacapan \% of vouacapans 2 and 3-4 showed better results, with a high recovery. The formulation that showed the best Vouacapan\% results was F3-MC, which had the highest active concentration, and consequently microencapsulation efficiencies over $44.38 \%, 86.95 \%$, and $99.49 \%$ for vouacapans 1,2 , and $3-4$, respectively.

\section{Thermal analysis}

By comparing blank microcapsules with FHPploaded microcapsules using DSC analysis (Figure 3(a) and (b)), it was possible to detect displacement of the exothermic peak from $578{ }^{\circ} \mathrm{C}$ to $467{ }^{\circ} \mathrm{C}$. This shift is caused by a decrease in thermal resistance caused by the interaction of the matrix with FHPp alginate/chitosan, thus demonstrating encapsulation.

When comparing the TGA curves of blank

TABLE I -Microencapsulation efficiency of FHPp (ME\%) and content of vouacapans microencapsulated (Vouacapan\%) obtained by GC-MS-SIM

\begin{tabular}{llcccc}
\hline & & FHPp & F1-MC & F2-MC & F3-MC \\
\hline ME (\%) & & - & $47.07 \pm 2.01$ & $57.17 \pm 1.63$ & $61.01 \pm 2.00$ \\
\hline Vouacapan 1 & Concentration $(\mu \mathrm{g} / \mathrm{mL}) \pm$ S.D. & $6.92 \pm 0.30$ & $0.28 \pm 0.13^{a}$ & $1.69 \pm 0.57^{b}$ & $3.04 \pm 0.28^{c}$ \\
& Vouacapan $(\%)$ & - & $4.04 \pm 1.78$ & $28.25 \pm 2.32$ & $44.38 \pm 1.59$ \\
\hline Vouacapan 2 & Concentration $(\mu \mathrm{g} / \mathrm{mL}) \pm$ S.D. & $18.45 \pm 0.36$ & $9.76 \pm 0.33^{a}$ & $12.85 \pm 1.10^{b}$ & $15.94 \pm 1.20^{c}$ \\
& Vouacapan $(\%)$ & - & $52.90 \pm 3.02$ & $69.23 \pm 1.41$ & $86.95 \pm 3.93$ \\
\hline Vouacapans 3-4 & Concentration $(\mu \mathrm{g} / \mathrm{mL}) \pm$ S.D. & $29.64 \pm 0.53$ & $19.32 \pm 0.72^{a}$ & $24.37 \pm 1.39^{b}$ & $28.90 \pm 1.75^{c}$ \\
& Vouacapan $(\%)$ & - & $65.37 \pm 2.64$ & $83.50 \pm 1.47$ & $99.49 \pm 2.80$ \\
\hline
\end{tabular}

$\overline{a, b}$ and $^{c}$ - One-way ANOVA post-hoc Tukey's test, specimens differ at $\mathrm{p}<0.05$. 
microcapsules with those of the microcapsules loaded with FHPp, as illustrated in Figure 3(c) and (d), we observed that the microencapsulation of FHPp resulted in an increase in water content. The first mass loss at a low temperature $\left(<200^{\circ} \mathrm{C}\right)$ corresponds to water desorption (Zohuriaan, Shokrolahi, 2004), and the second mass loss at a higher temperature $\left(>200{ }^{\circ} \mathrm{C}\right)$ is attributed to polymer degradation (Cozic et al., 2009).

It was also observed that the microencapsulation process protected FHPp from degradation, since the residual mass of FHPp alone was $0.11 \%$; however, on $\mathrm{F} 1-\mathrm{MC}$ this increased to $19.60 \%$ at the same temperature $\left(500^{\circ} \mathrm{C}\right)$. Similar thermal behavior was observed for the other microcapsules.

The thermal profile of the isolated polymers showed a broad endothermic peak between 25 and $100^{\circ} \mathrm{C}$, related to polymer dehydration, followed by decomposition. According to Czubenko and Druzynska (2009), the increased water content appears near the endothermic peak and drives the material to higher temperatures with increasing water content.

\section{XRD}

In the XRD analysis, the chitosans showed 2 peaks at about $10^{\circ}$ and $20^{\circ}$, corresponding to hydrated and anhydrous crystals, respectively (Figure 4a). These results are in agreement with those of Li et al. (2009). After microencapsulation, the typical chitosan peaks disappeared (Figure 4b) and the loaded microcapsules demonstrated an amorphous nature, similar to that of alginate. This suggested that the introduction of alginate on chitosan altered the crystalline structure of chitosan, probably preventing the formation of hydrogen bonds between the amino and hydroxyl groups (Li et al., 2009).

\section{FTIR}

The absorption spectrum in the infrared region of alginate (Figure 5a) showed absorption bands at $1613 \mathrm{~cm}^{-1}$ attributed to the stretch of $-\mathrm{COO}$, at $1101 \mathrm{~cm}^{-1}$ because of the stretch of -C-O-C-, and at $3443 \mathrm{~cm}^{-1}$ because of the stretch of the hydroxyl group linked by hydrogen bonds.
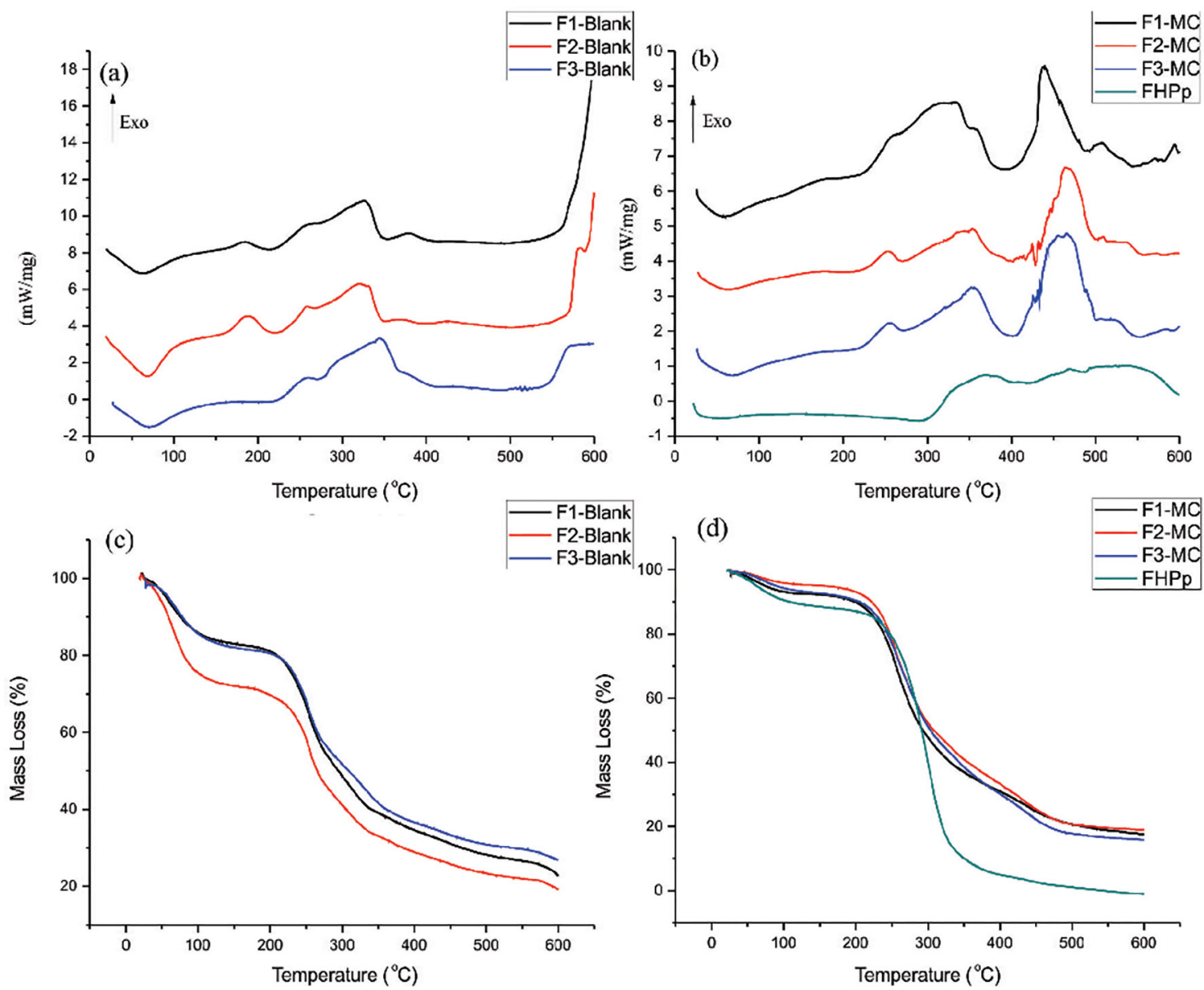

FIGURE 3 - Thermal analysis of blank microcapsules and FHPp-loaded microcapsules. DSC blank microcapsules (a), DSC FHPploaded microcapsules (b), TGA blank microcapsules (c) and TGA FHPp-loaded microcapsules (d). 


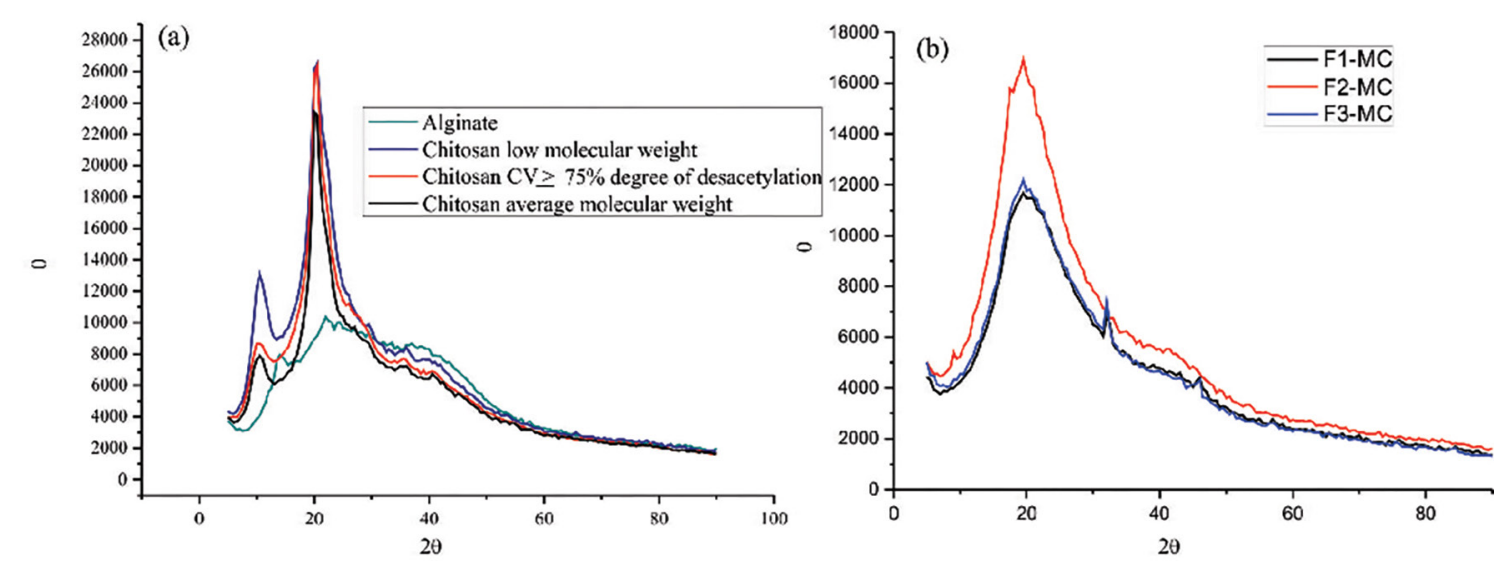

FIGURE 4 - X-ray diffraction of polymers (a), and from FHPp-loaded microcapsules (b).

Similar results have been observed by other authors (Lawrie et al., 2007; Pasparakis, Bouropoulos, 2006). According to Czubenko and Druzynska (2009), the vibrations at $2931 \mathrm{~cm}^{-1}$ are attributable to an aliphatic C-H stretch.

The absorption spectrum for low-molecular-weight chitosan (Figure $5 \mathrm{~b}$ ) showed absorption bands at $3425 \mathrm{~cm}^{-1}$ because of stretching of the hydroxyl group $(\mathrm{OH})$. In the region between 2875 and $2940 \mathrm{~cm}^{-1}$, the observed absorption bands were associated with $\mathrm{C}-\mathrm{H}$ stretching. The band that absorbed at $1642 \mathrm{~cm}^{-1}$ was a result of the predominance of the amino group $(\mathrm{N}-\mathrm{H})$. Similar results were found by Paulino et al. (2009) when they analyzed the infrared spectrum of chitosan.

In the infrared absorption spectrum of FHPp (Figure $5 \mathrm{c})$, we observed absorption bands at $1745 \mathrm{~cm}^{-1}$ attributed to the $\mathrm{C}=\mathrm{O}$ stretch of acetates. We also saw absorption
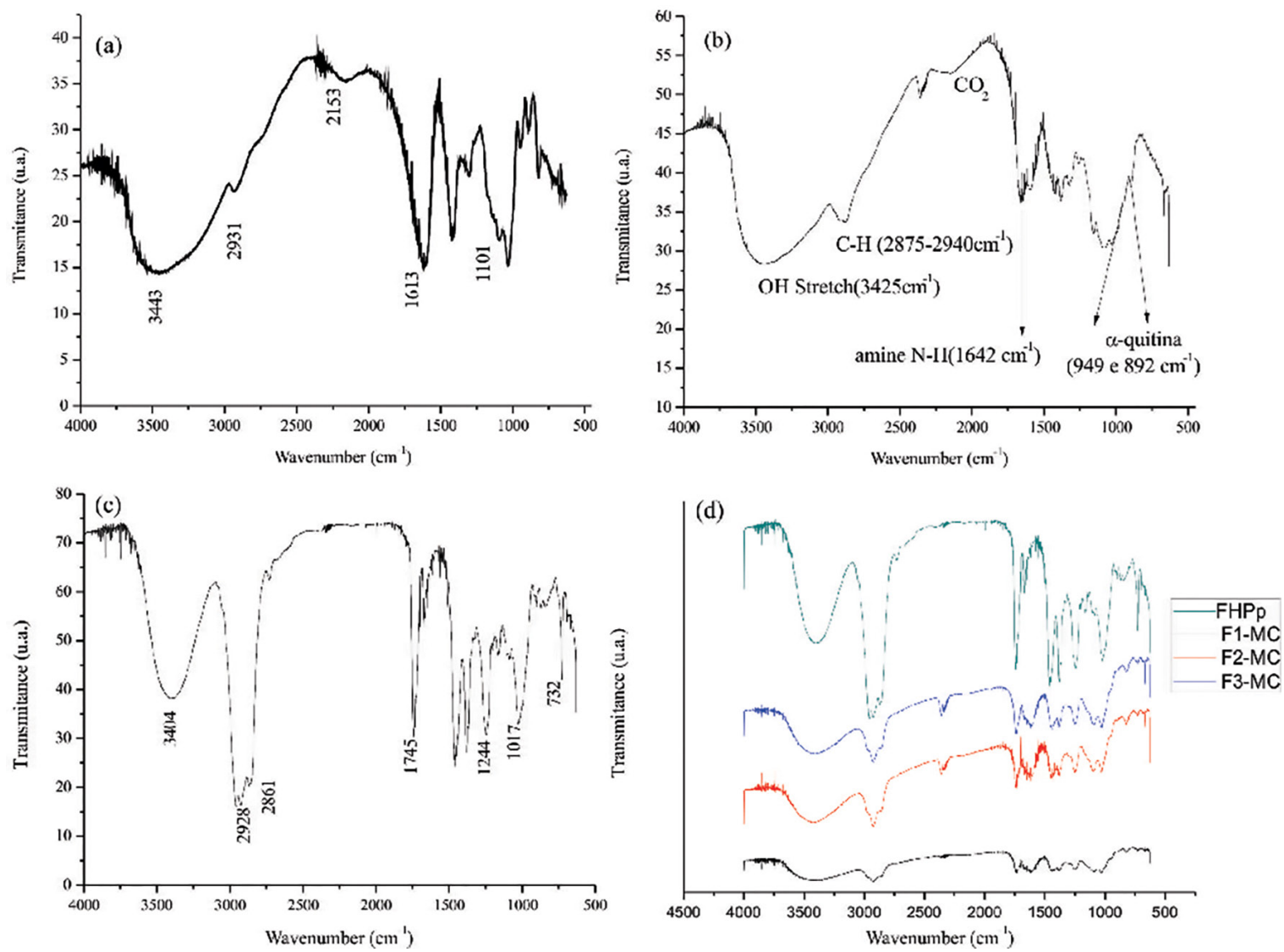

FIGURE 5 - FT-IR of alginate (a), of low molecular weight chitosan (b), of FHPp (c) and of FHPp-loaded microcapsules (d). 
at $1244 \mathrm{~cm}^{-1}$ (indicating the asymmetric $\mathrm{C}-\mathrm{O}$ stretch of acetate), at $1017 \mathrm{~cm}^{-1}$ (indicating asymmetric stretch of the C-O-C ester), and at $732 \mathrm{~cm}^{-1}$ (reflecting furan rings). This trait was also found by Spindola et al. (2009) when they analyzed $6 \alpha$-acetoxy,7 $\beta$-hydroxy-vouacapan.

On analysis of the samples of the loaded microcapsules (Figure 5d), we noted that the absorption bands at $3404 \mathrm{~cm}^{-1}$, and those between 2928 and $2861 \mathrm{~cm}^{-1}$ for FHPp were present in varying intensities in the microcapsules, which suggests a variable amount of microencapsulated oil.

\section{FT-Raman spectroscopy}

Characterization of different types of alginate reveals the presence of different proportions of guluronic and mannuronic acid units (Pereira et al., 2003). The presence of these acids can be determined from the characteristic features of their bands. While guluronic acid units originate from a band around $1025 \mathrm{~cm}^{-1}$, mannuronic acid originates at a band at approximately $1100 \mathrm{~cm}^{-1}$, as can be seen in Figure 6(a). Thus, the proportion of guluronic/ mannuronic acid concentration can be determined by their relative intensity. These bands were also used by Pereira et al. (2003) to characterize alginate. In the spectrum of low-molecular-weight chitosan (Figure 6b), we observed bands in the range of 2800-3000 $\mathrm{cm}^{-1}$, which is usually derived from stretching vibrations of $\mathrm{CH}$ groups (Socrates, 2001). Therefore, a band at $2881 \mathrm{~cm}^{-1}$ can be attributed to these vibrations. Bands at 1419, 1116, and $1094 \mathrm{~cm}^{-1}$ are associated with the vibrations of polysaccharide backbones, and bands at $1116 \mathrm{~cm}^{-1}$ and $1094 \mathrm{~cm}^{-1}$ may be considered indicative of the symmetric vibration of glycosidic bonds (Zhang et al., 2011). Analyzing the spectra for the FHPp-loaded microcapsules (Figure 6c) and comparing these with the FHPp spectra (Figure 6d), we found that a peak at $1673 \mathrm{~cm}^{-1}$ is characteristic of FHPp, and is present in all microcapsule samples, indicating that oil was microencapsulated. In general, for esters and monoesters of unsaturated dicarboxylic acids, the $\mathrm{C}=\mathrm{O}$ bandwidth occurs approximately within the same range $\left(1735-1760 \mathrm{~cm}^{-1}\right)$. With $\beta$-keto esters, tautomerism is
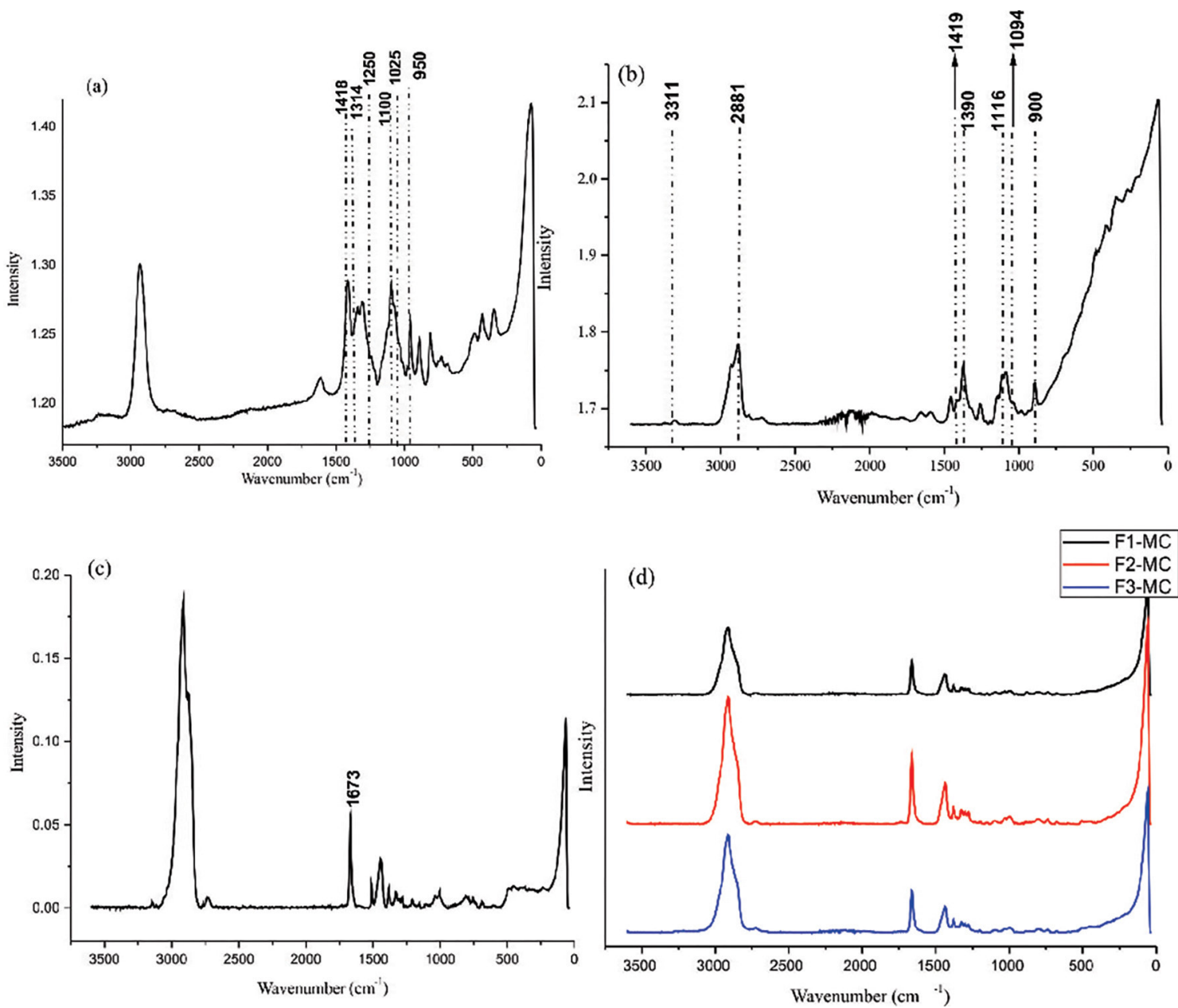

FIGURE 6 - FT-Raman of alginate (a), low molecular weight chitosan (b), of the FHPp (c) and FHPp-loaded microcapsules (d). 
possible (Socrates, 2001). In the case of tautomers, a strong band is observed at $1650 \mathrm{~cm}^{-1}$. The peak at $1673 \mathrm{~cm}^{-1}$ is reflective of the ester group (i.e., the vouacapans present in FHPp), where the effect of hydrogen bonding occurs. When an intramolecular hydrogen bond (internal) is present, the $\mathrm{C}=\mathrm{O}$ bond shifts to a lower frequency. The two most striking features in the spectrum of a normal ester are the strong $\mathrm{C}=\mathrm{O}$ band, which appears between 1735 and $1750 \mathrm{~cm}^{-1}$, and stretch $\mathrm{C}-\mathrm{O}$ bond bands, which appear between 1300 and $1000 \mathrm{~cm}^{-1}$ (Pavia et al., 2010).

\section{In vitro release profile}

The release profile of the FHPp-loaded microcapsules was generated by measuring vouacapans in FHPp. There was no statistically significant change between the average percentage of vouacapans released in F2-MC and F3-MC after $24 \mathrm{~h}$ (Figure 7); however, it was observed that the release of F3-MC appears to be more accelerated, which could be valuable for oral formulations. We observed that after $3 \mathrm{~h}(\mathrm{pH} 1.2)$, vouacapan release from F3-MC was $53.85 \pm 0.44 \%$, suggesting that the FHPp may be primarily located at the alginate/chitosan interface, a fact made possible by the chitosan-induced relaxation of the polymer mesh.

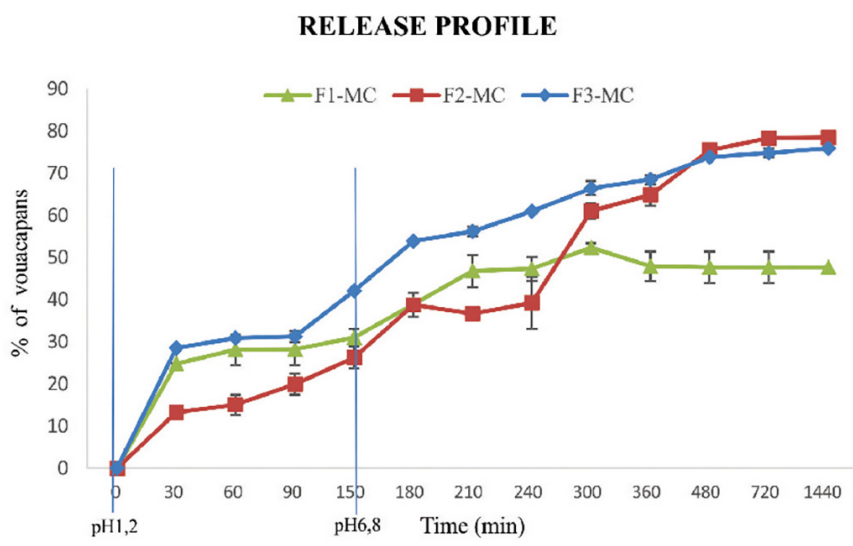

FIGURE 7 - In vitro release profile of FHPp-loaded microcapsules.

After $24 \mathrm{~h}$ ( $\mathrm{pH} 6.8$ ), the release of vouacapans from F3-MC was $75.88 \pm 0.45 \%$, slightly lower than that from F2-MC (78.41 $\pm 2.23 \%)$; in contrast, vouacapan release from $\mathrm{F} 1-\mathrm{MC}$ was $47.64 \pm 2.50 \%$, which was significantly lower than the results obtained with the other two formulations.

According to Ribeiro et al. (2005), there is a lack of knowledge about the behavior of alginate microspheres in simulated gastric and intestinal fluids; however, it is known that the stability of the alginate/chitosan complex can be influenced by environmental parameters such as $\mathrm{pH}$ and ionic strength. Two hours under simulated gastric conditions can lead to the dissociation of the alginate matrix (Shu, Zhu, Song, 2001), providing evidence that this polymers not the limiting factor for the complete liberation of vouacapans.

According to Mi et al. (2002), the ability of alginate/ chitosan microcapsules to swell depends on the $\mathrm{pH}$ value. The lower the $\mathrm{pH}$, the greater the swelling, and at $\mathrm{pH}>6.0$, the degree of swelling is reduced. The increased swelling at $\mathrm{pH}<2.0$ is due to the protonation of chitosan, while the slight increase in swelling at $\mathrm{pH}>5.0$ is attributable to the ionization of the carboxylic group of alginate within the alginate/chitosan complex. This is important because the degree of swelling influences the process of diffusion, with increased swelling being associated with a higher diffusion rate. Microcapsules produced with low-molecular-weight chitosan showed less swelling compared to that shown by the microcapsules prepared using larger-molecular-weight chitosans when applied in delivery systems, and were associated with decreased diffusion (Liu et al., 2004).

Several authors have reported a similar percentage release of various drugs from alginate/chitosan beads, demonstrating that these polymer coatings decrease drug release from microcapsules (Anal, Stevens, 2005; González-Rodríguez et al., 2002; Rajendran, Basu, 2009; Yu et al., 2008).

We next examined release kinetics to determine which model provided the best fit for the data. We tested first-order Q (Mt / M $\infty=\mathrm{Qt}=\ln$ '. $\mathrm{t}$ ) and second-order $(\mathrm{Mt} / \mathrm{M} \infty=\mathrm{Qt}=(1 / \mathrm{Q})$. $\mathrm{t})$ models, as well as the model proposed by Higuchi ( $\mathrm{Mt} / \mathrm{M} \infty=\mathrm{Q}_{0}+\mathrm{KH} \mathrm{t}_{1 / 2}$ ), for all formulations.

Following Fick's law, Mt/M $\infty=\mathrm{k} \cdot t^{\mathrm{n}}$ and $\log \mathrm{Mt} / \mathrm{M} \infty$ $=\log \mathrm{k}+\mathrm{n} \log t$ constant values were obtained: a value of $\mathrm{n}=0.45$ indicates Case I (Fickian) diffusion or square root of time kinetics, $0.45>\mathrm{n}<0.89$ indicates anomalous (nonFickian) diffusion, $\mathrm{n}=0.89$ indicates Case II transport, and $\mathrm{n}>0.89$ indicates super case II transport (Ritger, Peppas, 1987).

For F1-MC, it was found that the best fit was provided by Higuchi's model $(\mathrm{R}=0.9382 \pm 0.0136)$, by Fick's law of diffusion, $\mathrm{n}=1.5347(\mathrm{n}>1), \mathrm{r}=0.9664 \pm 0.0118$, and $\mathrm{k}=1.37$. However, for F2-MC, the best kinetics model was first order $(\mathrm{R}=0.9713 \pm 0.0290)$, by Fick's law of diffusion $\mathrm{n}=1.3733(\mathrm{n}>1), \mathrm{r}=0.9878 \pm 0.0118$, and $\mathrm{k}$ $=1.14$. It was found that the best fit was also provided by Higuchi's model with $\mathrm{R}=0.8782 \pm 0.0136$ for F3-MC, with diffusional $\mathrm{n}=1.6084$, i.e., $\mathrm{n}>1, \mathrm{r}=0.9525 \pm 0.0118$, and $\mathrm{k}=1.55$. 
The $n$ value $(n>1)$ indicates that the release mechanism is of the super case II type, in which the simultaneous contribution of processes such as diffusion, swelling, relaxation, and erosion of the polymeric matrix does not obey a Fickian diffusion model (Korsmeyer et al., 1983; Peppas, 1985; Ritger, Peppas, 1987). In the non-Fickian diffusion process, the polymeric chains do not have enough mobility to allow fast penetration of the solvent into the polymer matrix.

\section{CONCLUSIONS}

The data revealed that the chemical profile of FHPp was not altered by the microencapsulation process. Thermal and spectroscopic analysis in the infrared region revealed that FHPp was microencapsulated and that the process protected the obtained fraction from degradation. The crystalline chitosan structure was changed with the introduction of alginate, yielding amorphous microcapsules.

Although microcapsules developed with alginate/ chitosan with a deacetylation rate $\geq 75 \%$ (F2-MC) showed a lower mean diameter, the $\mathrm{ME} \%$ of the oleaginous fraction and content of microencapsulated vouacapans were greater than when using the combination of alginate/ low-molecular-weight chitosan (F3-MC). The best model to describe the release kinetics was that proposed by Higuchi for F1-MC and F3-MC; however, for F2-MC, the first-order model was used, and the release mechanism was of the supercase II type for all formulations.

The most promising pre-formulation (F3-MC) needs further examination in order to produce a final formulation, and its ex vivo and in vivo stability should also be determined.

\section{ACKNOWLEDGEMENTS}

The authors are grateful to Financiadora de Estudos e Projetos (FINEP), Coordenadoria de Aperfeiçoamento de Pessoal do Ensino Superior (CAPES), and Conselho Nacional de Desenvolvimento Científico e Tecnológico (CNPq) for their financial support. They also acknowledge the Antonio Medina Neto for the DSC and TGA analysis and Edson Marques dos Reis for GC-MS analysis.

\section{REFERENCES}

ANAL, A.K.; STEVENS, W.F. Chitosan-alginate multilayer beads for controlled release of ampicillin. Int. J. Pharm., v.290, p.45-54,2005.
BARBER, T.A. Particle population analysis. In: BARBER, T.A. (Ed.). Pharmaceutical particulate matter: analysis and control. Buffalo Grove: Interfarma, 1993. p.266-303.

CARVALHO, J.C.T.; SERTIE, J.A.A.; BARBOSA, M.V.J.; PATRICIO, K.C.M.; CAPUTO, L.R.G.; SARTI, S.J.; FERREIRA, L.P., BASTOS, J.K. Anti-inflammatory activity of the crude extract from the fruits of Pterodon emarginatus Vog. J. Ethnopharmacol., v.64, p.127133,1999.

COELHO, L.P.; REIS, P.A.; CASTRO, F.L.; GAYER, C.R.M.; LOPES, C.S.; SILVA, M.C.C.; SABINO, K.C.C.; TODESCHINI, A.R.; COELHO, M.G.P. Antinociceptive properties of ethanolic extract and fractions of Pterodon pubescens Benth. seeds. J. Ethnofarmacol., v.98, p.109116,2005 .

COZIC, C.; LICTON, L.; GARDA, M.R.; MARLHOUX, F.; CERF, D.L. Analysis of Arabic gum: Study of degradation and water desorption processes. Food Hydrocolloid, v.23, p.1930-1934, 2009.

CZUBENKO, J.O.; DRUZYNSKA, M.G. Effect of ionic crosslinking on the water state in hydrogel chitosan membranes. Carbohydr.Polym., v.77, p.590-598,2009.

GONZÁLEZ-RODRÍGUEZ, M.L.; HOLGADO, M.A.; SÁNCHEZ-LAFUENTE, C.; RABASCO, A.M.; FINI, A. Alginate/chitosan particulate systems for sodium diclofenac release. Int. J. Pharm., v.232, p.225-234, 2002.

HOSCHEID, J.; REINAS, A.; CORTEZ, D.A.G.; COSTA, W.F.; CARDOSO, M.L.C. Determination by CG-MSSIM of furanoditerpenes in Pterodon pubescens Benth.: development and validation. Talanta, v.100, p.372-376, 2012.

HOSCHEID, J.; BERSANI-AMADO, C.A.; ROCHA, B.A.; OUTUKI, P.M.; SILVA, M.A.R.C.P.; FROEHLICH, D.L.; CARDOSO, M.L.C. Inhibitory effect of the hexane fraction of the ethanolic extract of the fruits of Pterodon pubescens Benth in acute and chronic inflammation. Evid. Based Compl. Alt. Med., v.2013, p.1-7, art. n. 272795, 2013.

KORSMEYER, R.W.; GURNY, R., DOELKER, E.; BURI, P.; PEPPAS, N.A. Mechanisms of solute release from porous hydrophilic polymers. Int. J. Pharm., v.15, p.25-35, 1983. 
KRUIF, C.G.; WEINBRECK, F.; VRIES, R. Complex coacervation of proteins and anionic polysaccharides. Curr. Opin. Colloid Interface Sci., v.9, p.340-349, 2004.

LAWRIE, G.; KEEN, I.; DREW, B.; CHANDLER-TEMPLE, A.; RINTOUL, L.; FREDERICKS, P.; GRØNDAH, L. Interactions between alginate and chitosan biopolymers characterized using FTIR and XPS. Biomacromolecules, v.8, p.2533-2541, 2007.

LI, X.; XIE, H.; LIN, J.; XIE, W.; MA, X. Characterization and biodegradation of chitosan-alginate polyelectrolyte complexes. Polym. Degrad. Stabil., v.94, p.1-6, 2009.

LIU, X.; XUE, W.; LIU, Q.; YU, W.; FU, Y.; XIONG, X.; MA, $\mathrm{X}$; YUAN, Q. Swelling behaviour of alginate-chitosan microcapsules prepared by external gelation or internal gelation technology. Carbohydr. Polym., v.56, p.459-464, 2004.

MAHKAM, M. Modification of nano alginate-chitosan matrix for oral delivery of insulin. Nat. Sci., v.7, p.1-7, 2009.

MI, F.L.; SUNG, H.W.; SHYU, S.S. Drug release from chitosanalginate complex beads reinforced by a naturally occurring cross-linking agent. Carbohydr. Polym.,v.48, p.61-72, 2002.

MiguEL, M.D., MiGUEL, O.G. Desenvolvimento de fitoterápicos. São Paulo: Robe, 1999. p.27-41.

MLADENOVSKA, K.; CRUAUD, O.; RICHOMME, P.; BELAMIE, E.; RAICKI, R.S.; VENIER-JULIENNE, M.C.; POPOVSKI, E.; BENOIT, J.P.; GORACINOVA, K. 5-ASA loaded chitosan-Ca-alginate microparticles: Preparation and physicochemical characterization. Int. J. Pharm., v.345, p.59-69, 2007.

MORS, W.B.; FASCIO, M.; MONTEIRO, H.J.; GILBERT, B.; PELLEGRINO, J. Chemoprophylactic agent in schistosomiasis: 14,15-epoxygeranylgeraniol. Science, v.157, p.950-951, 1967.

NESTERENKO, A.; ALRIC, I.; SILVESTRE, F.; DURRIEU, $\mathrm{V}$. Vegetable proteins in microencapsulation: A review of recent interventions and their effectiveness. Ind. Crop. Prod., v.42, p.469-479, 2013.

NUNAN, E.A.; CARVALHO, M.G.; PILOVELOSO, D. Furanediterpenes with anti- and proinflammatory activity. Braz. J. Med. Biol. Res., v.15, p.450-451, 1982.
PASPARAKIS, G.; BOUROPOULOS, N. Swelling studies and in vitro release of verapamil from calcium alginate and calcium alginate-chitosan beads. Int. J. Pharm., v.323, p.34-42, 2006.

PAULINO, A.T.; GUILHERME, M.R.; DE ALMEIDA, E.A.M.S.; PEREIRA, A.G.B.; MUNIZ, E.C.; TAMBOURGI, E.B. One-pot synthesis of a chitosan-based hydrogel as a potential device for magnetic biomaterial. $J$. Magn. Magn. Mater., v.17, p.2636-2642, 2009.

PAVIA, D.L.; LAMPMAN, G.M.; KRIZ, G.S.; VYVYAN, J.R. Espectroscopia no infravermelho. In PAVIA, D.L.; LAMPMAN, G.M.; KRIZ, G.S.; VYVYAN, J.R. (Eds.). Introdução à espectroscopia. 4.ed. São Paulo: Cengage Learning Edições Ltda, 2010. p.64-65.

PENICHE, C.; HOWLAND, I.; CARRILLO, O.; ZALDÍVAR, C.; ARGÜELLES-MONAL, W. Formation and stability of shark liver oil loaded chitosan/calcium alginate capsules. Food Hydrocolloid, v.18, p.865-871, 2004.

PEPPAS, N.A. Analysis of Fickian and non-Fickian drug release from polymers. Pharm. Acta Helv.,v.60, p.110-111,1985.

PEREIRA, L.; SOUSA, A.; COELHO, H.; AMADO, A.M.; RIBEIRO-CLARO, P.J.A. Use of FTIR, FT-Raman and 13C-NMR spectroscopy for identification of some seaweed phycocolloids. Biomol. Enq., v.20, p.223-228, 2003.

RAJENDRAN, A.; BASU, S.K. Alginate-chitosan particulate system for sustained release of nimodipine. Trop. J. Pharm. Res., v.8, p.433-440, 2009.

RIBEIRO, A.J.; SILVA, C.; FERREIRA, D.; VEIGA, F. Chitosan-reinforced alginate microspheres obtained through the emulsification/internal gelation technique. Eur. J. Pharm. Sci., v.25, p.31-40, 2005.

RITGER, P.L.; PEPPAS, N.A. A simple equation for description of solute release I. Fickian and non-fickian release from non-swellable devices in the form of slabs, spheres, cylinders or discs. J. Control. Release, v.5, p.23-36, 1987.

SCHMITT, C.; SANCHEZ, C.; DESOBRY-BANON, S.; HARDY, J. Structure and techno functional properties of protein-polysaccharide complexes: a review. Crit. Rev. Food Sci. Nutr., v.38, p.689-753,1998. 
SHI, P.; HE, P.; THE, T.K.H.; MORSI, Y.S.; GOH, J.C.H. Parametric analysis of shape changes of alginate beads. $A d v$. Powder Technol., v.210, p.60-66, 2011.

SHU, X.Z.; ZHU, K.J.; SONG, W. Novel pH-sensitive citrate cross-linked chitosan film for drug controlled release. Int. J. Pharm., v.212, p.19-28, 2001.

SILVA, M.C.C.; GAYER, C.R.M.; LOPES, C.S.; CALIXTO, N.O.; REIS, P.A.; PASSEAS, C.P.B.; PAES, M.C.; DALMAU, S.R.; SABINO, K.C.C.; TODESCHINI, A.R.; COELHO, M.G.P. Acute and topic anti-edematogenic fractions isolated from the seeds of Pterodonpubescens. $J$. Pharm. Pharmacol., v.55, p.135-141, 2004.

SOCRATES, G. The carbonyl group: $\mathrm{C}=\mathrm{O}$. In: SOCRATES, G. (Ed.) Infrared and raman characteristic group frequencies: tables and charts. 3.ed. Chichester: John Wiley, 2001. p.147-148.

SPINDOLA, H.M.; CARVALHO, J.E.; RUIZ, A.L.T.G.; RODRIGUES, A.F.R.; DENNY, C.; SOUSA, I.M.O.; TAMASHIRO, J.Y.; FOGLIO, M.A. Furanoditerpenes from Pterodon pubescens Benth with selective in vitro anticancer activity for prostate cell line. J. Braz. Chem. Soc., v.20, p.569-575, 2009.

SPINDOLA, H.M.; SERVAT, L.; DENNY, C.; RODRIGUES, R.A.F.; EBERLIN, M.N.; CABRAL, E.; SOUSA, I.M.O.; TAMASHIRO, J.Y.; CARVALHO, J.E.; FOGLIO, M.A. Antinociceptive -dihydroxyvouacapan-17 $\beta$-oate methyl ester isolated from Pterodon pubescens Benth. BMC Pharmacol., v.10, p.1-10, 2010.

SUAVE, J.; DALLAGNOL, E.C.; PEZZIN, A.P.T.; SILVA, D.A.K.; MEIER, M. M.; SOLDI, V. Microencapsulação: inovação em diferentes áreas. Saúde \& Amb. Rev., v.7, p.12-20, 2006.
UDDIN, M.S.; HAWLADER, M.N.A.; ZHU, H.J. Microencapsulation of ascorbic acid: effect of process variables on product characteristics. J. Microencapsul., v.18, p.199-209, 2001.

UNITED STATES PHARMACOPEIA. 32-National Formulary 27. Rockwell, USP, 2009.

VENKATRAMAN, S.; DAVAR, N.; CHESTER, A.; KLEINER, L. An overview of controlled release systems. In: WISE, D.L. (Ed.). Handbook of pharmaceutical controlled release technology. New York: Marcel Dekker, 2000. p.431-463.

VIEIRA, C.R.; MARQUE, M.F.; SOARES, P.R.; MATUDA, L.; OLIVEIRA, C.M.A.; KATO, L.; SILVA, C.C.; GUILLO, L.A. Antiproliferative activity of PterodonpubescensBenth. seed oil and its active principle on human melanoma cells. Phytomedicine, v.15, p.528-532, 2008.

YU, C.Y.; ZHANG, X.C.; ZHOU, F.Z.; ZHANG, X.Z.; CHENG, S.X.; ZHUO, R.X. Sustained release of antineoplastic drugs from chitosan-reinforced alginate microparticle drug delivery systems. Int. J. Pharm., v.357, p.15-21, 2008.

ZHANG, K.; PESCHEL, D.; HELM, J.; GROTH, T.; FISCHER, S. FT Raman investigation of novel chitosan sulfates exhibiting osteogenic capacity. Carbohydr. Polym., v.83, p.60-65, 2011.

ZOHURIAAN, M.J.; SHOKROLAHI, F. Thermal studies on natural and modified gums. Polym. Test., v.23, p.575-579, 2004.

Received for publication on $17^{\text {th }}$ December 2013 Accepted for publication on $18^{\text {th }}$ June 2014 